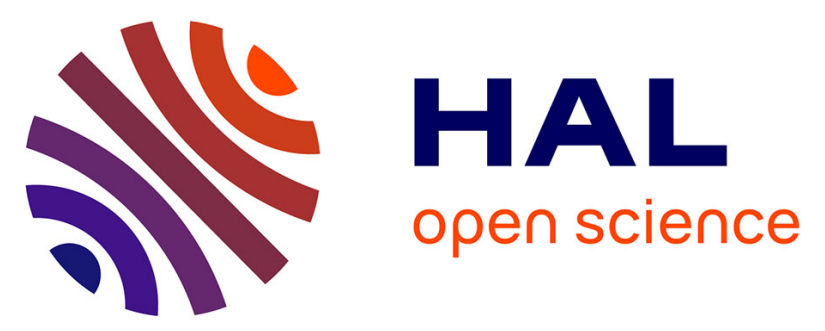

\title{
Effects of a targeted shrimp (Penaeus notialis) exploitation on fish catches in the Gambia estuary .
}

Raymond Laë, Jean-Marc Ecoutin, Asber Mendy, Jean Raffray, Jean-Yves Weigel, Omar Sadio, Ousmane Djobe

\section{- To cite this version:}

Raymond Laë, Jean-Marc Ecoutin, Asber Mendy, Jean Raffray, Jean-Yves Weigel, et al.. Effects of a targeted shrimp (Penaeus notialis) exploitation on fish catches in the Gambia estuary .. Aquatic Living Resources, 2004, 17, pp.75 - 85. 10.1051/alr:2004010 . ird-01079948

\section{HAL Id: ird-01079948 https://hal.ird.fr/ird-01079948}

Submitted on 4 Nov 2014

HAL is a multi-disciplinary open access archive for the deposit and dissemination of scientific research documents, whether they are published or not. The documents may come from teaching and research institutions in France or abroad, or from public or private research centers.
L'archive ouverte pluridisciplinaire HAL, est destinée au dépôt et à la diffusion de documents scientifiques de niveau recherche, publiés ou non, émanant des établissements d'enseignement et de recherche français ou étrangers, des laboratoires publics ou privés. 


\title{
Effects of a targeted shrimp (Penaeus notialis) exploitation on fish catches in the Gambia estuary
}

\author{
Raymond Laë ${ }^{1, a}$, Jean-Marc Ecoutin ${ }^{1}$, Asber Mendy ${ }^{2}$, Jean Raffray ${ }^{1}$, Jean-Yves Weigel ${ }^{1}$, Omar Sadio ${ }^{1}$ \\ and Ousmane Djobe ${ }^{2}$ \\ 1 IRD, BP 1386, Dakar, Senegal \\ 2 Fisheries Department of the Gambia, 6 Col. Muammar Ghaddafi Avenue, Banjul, The Gambia
}

Received 23 July 2003; Accepted 23 January 2004

\begin{abstract}
Results of an annual survey of fishing activities and catches in the Gambia estuary (200 km long), carried out from June 2001 to May 2002, indicated that fishing effort targets mainly (66\% of fishing trips) shrimps. As a result of the globalisation of fish markets, the fishery has become a quasi mono-exploitation of shrimp for exporting. At the opposite, fishing activities focusing on fish were low and carried out with large and medium mesh drift nets, gill nets and surrounding nets (17\% of fishing trips), handlines and longlines (15\%). The annual catch, estimated at 2350 tonnes for the estuarine part of the River Gambia, consisted of $1800 \mathrm{t}$ of fish and $550 \mathrm{t}$ of shrimp. Stownets were the most efficient gear accounting for 50\% of the total production (550 t of shrimp and $600 \mathrm{t}$ of fish) while other significant techniques were mainly drift nets $(21 \%)$, longlines $(11 \%)$ and gillnets $(5 \%)$. Fish catches were composed with 55 fish species among which 16 species accounted for $90 \%$ of the annual catch. The average catch length of these first sixteen species was $295 \mathrm{~mm}$, clearly demonstrating that fishing for fish was targeting large fish. The effects of the targeted shrimp exploitation resulted in a low fishing effort for fish leading to low fish landings and consequently to an under exploitation of fish resource in the Gambia estuary.
\end{abstract}

Key words: Artisanal fisheries / Gambia estuary / Fish statistics / Finfish / Shrimp / Mono-exploitation

\begin{abstract}
Résumé - Impacts d'une exploitation spécialisée de la crevette (Penaeus notialis) sur les captures de poisson dans l'estuaire de la Gambie. Les résultats d'un suivi annuel des activités de pêche et des captures dans l'estuaire de la Gambie (200 km de long), mené de juin 2001 à mai 2002, montrent que l'effort de pêche était principalement concentré sur l'exploitation de la crevette ( $66 \%$ des sorties de pêche). Suite à la mondialisation des marchés, la pêcherie a évolué vers une quasi mono exploitation de la crevette, les produits étant destinés à l'exportation. A l'inverse, les activités ciblant le poisson étaient faibles et menées à l'aide de filets dérivants, dormants ou encerclants à larges ou moyennes mailles (17\% des sorties de pêche), de lignes à main et de palangres (15\%). Les captures annuelles, estimées à 2350 tonnes pour la partie estuarienne du fleuve Gambie, comprenaient $1800 \mathrm{t}$ de poisson et $550 \mathrm{t}$ de crevette. Les filets à crevettes étaient les plus efficaces capturant $50 \%$ de la production totale (550 t de crevette et $600 \mathrm{t}$ de poisson). Les autres engins intervenant significativement dans les captures étaient principalement les filets dérivants $(21 \%)$, les palangres $(11 \%)$ et les filets dormants $(5 \%)$. Les prises de poisson étaient composées de 55 espèces parmi lesquelles les seize premières représentaient $90 \%$ des captures annuelles. La moyenne des tailles de capture de ces seize espèces était élevée $(295 \mathrm{~mm})$, indiquant clairement que l'effort de pêche se concentrait sur des espèces et/ou individus de grande taille. Les conséquences de la forte spécialisation des pêcheries sur la crevette se traduisent par un faible effort de pêche sur le poisson conduisant à de faibles captures totales et en définitive à une sous exploitation de la ressource en poisson dans l'estuaire.
\end{abstract}

\section{Introduction}

In West Africa, most of the estuaries have been affected by habitat degradation due to the exploitation of mangrove forests and/or reduced freshwater inflows mainly resulting from dam construction and drought periods. These different perturbations have been mentioned in Senegal, in the Saloum

\footnotetext{
a Corresponding author: lae@ird.sn
}

estuary (Kebe 1994; Diouf 1996; Bousso 1996) and the River Casamance (Albaret 1987) where severe hydrological modifications were characterized by hyperhalinity and reversed salinity gradient ranging from 36 psu at the mouth to more than 150 psu upstream. In the same region the Gambia river, located to the south of the Sine Saloum estuary and to the north of the Casamance estuary, was less affected by the different drought periods that affected the Sahelian region since the last thirsty years. This estuary did not suffer these natural 
perturbations because it has a much larger catchment extending to the Guinea uplands that are considered as the water tower of West Africa (Lamagat et al. 1990). Hence although water discharge significantly decreases during the dry season, it is still sufficient to maintain an upstream-downstream salinity gradient in the estuary, with seasonal variations due to water input in the wet season. As industrial activities and farming are also reduced, this estuary seems to be an exception in the sub region and could be qualified as healthy environment.

Usually, estuaries are a focus of human activities such as fishing, farming, manufacturing, shipping and among these ecosystems, tropical and subtropical estuaries are one of the most exploited in the world. Most tropical estuaries are vitally important as a source of fish to the local people, and fishing plays an important role in the economy (Blaber 2000). Although commercial fisheries are rare in these areas, subsistence and artisanal fisheries have evolved and are now threatened by over-exploitation resulting from a huge increase in fishing effort and a use of illegal fishing gear or techniques. As a consequence, even in developing countries, estuaries are generally heavily exploited by artisanal fisheries as it is the case for the Sine Saloum and Casamance estuaries (Le Reste 1986; Bousso 1996). In the Gambia, in the absence of any regular monitoring of the fisheries, it was difficult to obtain reliable estimates of fishing effort and catches in the estuarine area. No time series were available and only some exceptional studies were carried out (King 1979; Lesack and Drammeh 1980; Lesack et al. 1984; Dorr et al. 1985; Lesack 1986; Njai 2000). Nevertheless, from this work, it emerged that the situation could be different from the adjoining estuaries, because fishing activities mainly involved foreigner fishermen and concentrated on shrimps at the detriment of fish fishing. Catches were usually estimated at $1200-1500 \mathrm{ty}^{-1}$, half of which comes from the estuarine part of the river. The number of fishermen was estimated to be about $3000,83 \%$ of whom operated in the estuary. Seasonal shrimping occupied more than 1000 people at the height of activity. Difficulties in marketing and the lack of fish processing and preservation infrastructure were considered to be major limiting factors for fishing in the Gambia.

Facing this unusual situation for a developing country, our purpose, as shrimp activities seemed to be the most developed, was to understand what could be the effects of a targeted shrimp exploitation on fish fishing. One preliminary condition was to collect reliable data on artisanal fisheries through an annual survey carried out in the Gambia estuary from June 2001 to May 2002. This included an assessment of the status of the fishery, exploitation levels, fishing methods and seasonal variability.

\section{Materials and methods}

\subsection{Study area}

The Gambia river is located at the western edge of West Africa (Fig. 1). It originates in the Fouta Djalon plateau of northern Guinea and flows $1200 \mathrm{~km}$ through southern Senegal and the Gambia to the Atlantic Ocean. The total area of the Gambia river basin is $78000 \mathrm{~km}^{2}$, but the estuarine subdivision is limited to the part from Kaur to Banjul. From this area

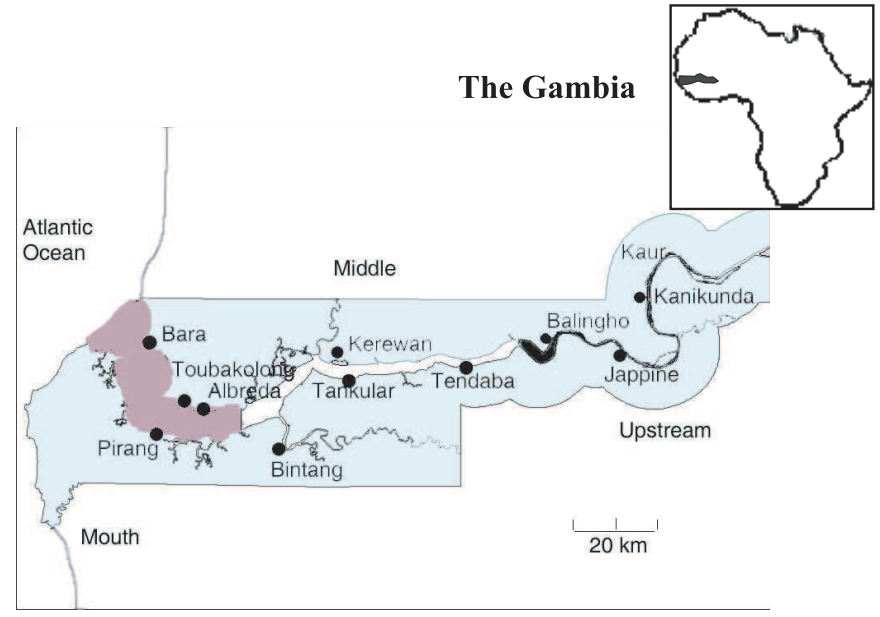

Fig. 1. Stratification of the Gambia estuary into three geographical strata (mouth: grey, middle: white and uspstream: black) based on the spatial and temporal variations in salinity. Black spots are the 11 sampled villages during the survey, 2001-2002.

to the mouth, the entry of marine water gives rise to saline floodplains covered with a dense mangrove composed mainly with Rhizophora mangle. The mangrove of the Gambia have very big trees because of large freshwater and marine input (Marius 1985).

The river flows into the Atlantic Ocean through a $13 \mathrm{~km}$ wide mouth which together with a maximum tidal amplitude of $2 \mathrm{~m}$ allows mass entries of sea water into the estuary. The mangroves play an important role for fish in the Gambia estuary as they form feeding and breeding grounds for very many species, and they are a major source of trophic enrichment (Thayer et al. 1987; Vance et al. 1990; Ronnback et al. 1999; Blaber 2000).

The climate (Albaret et al. 2004) is dominated alternately by the dry harmattan air, which originates in the Sahara and a south-westerly monsoon of humid oceanic air. Rains occur from June to October, with the greatest precipitation in August. There is also a marked hydrological seasonality in the Gambia River leading to the definition of three main seasons: 1) flow from July to October, 2) fall from November to February and 3) low water from Marsh to June. As a result of freshwater input, salinity is low $(0-10)$ in the upstream and middle area from August to January (wet season). Then in February, salinity increases progressively until July when it reaches its highest value, close to that of sea water at Tendaba (dry season).

\subsection{Fisheries sampling procedures}

The study site was the lower river of the Gambia estuary, which means the area subjected to marine influence $(200 \mathrm{~km}$ upstream during the dry season). Information on fish resources and fishing effort was collected from studies of fishermen activities. Data were obtained by sampling small-scale fisheries during a complete annual cycle from June 2001 to May 2002. The total number of fishermen, estimated to be 2500 , included full-time (exclusively fishermen) and part-time (fishermen/farmers or fishermen/craftsmen) fishermen (on the basis 
Table 1. Codification and number of fish and shrimp species measured per geographical area in the Gambia estuary.

\begin{tabular}{|c|c|c|c|c|c|}
\hline Species & Code & Mouth & Middle & Upstream & Total \\
\hline Arius spp. & Ari & 9993 & 10700 & 790 & 21483 \\
\hline Cynoglossus spp. & Cyn & 3945 & 3193 & 253 & 7391 \\
\hline Ethmalosa fimbriata & Efi & 911 & 4034 & 716 & 5661 \\
\hline Ilisha africana & Iaf & 1807 & 1839 & 80 & 3726 \\
\hline Liza grandisquamis & Lgr & 1539 & 4436 & 346 & 6321 \\
\hline Penaeus notialis & Pdu & 9656 & 4522 & 1087 & 15265 \\
\hline Pseudotolithus elongatus & Pel & 6822 & 11879 & 2940 & 21641 \\
\hline Pomadasys spp. & Pom & 2624 & 201 & 86 & 2911 \\
\hline Polydactylus quadrifilis & Poq & 191 & 4653 & 3289 & 8133 \\
\hline Pentanemus quinquarius & Pqq & 5959 & 2026 & 44 & 8029 \\
\hline Pseudotolithus senegalensis & Psn & 2949 & 905 & 397 & 4251 \\
\hline Sarotherodon melanotheron & Sme & 31 & 641 & 998 & 1670 \\
\hline Total & & 46427 & 49029 & 11026 & 106482 \\
\hline
\end{tabular}

of the time they spend fishing), with their numerous assistants. As the definition of fishermen and assistants is vague in developing countries, the fishing unit used was the active fishing canoes making a real contribution to fishing effort.

The study period spanned one hydrological cycle of the estuary, which also corresponded to one biological cycle for fish and the fishery. The monitoring was based on two stratifications:

1) geographical stratification of the estuary into three homogeneous sectors (Fig. 1) corresponding to variations in salinity and fish community composition,

2) stratification of the fishery based on two different classes of fishermen (shrimpers and fish fishermen).

The mouth and middle sectors included four sampling villages each, respectively Albreda, Barra, Pirang, Toubakolong, and Bintang, Kerewan, Tankular, Tendaba. The third sector included three villages: Balingo, Jappeni and Kanikunda. Each of these villages was sampled over a ten days period per month. Monthly census, daily capture and fishing effort data were collected independently at every sampling site:

- A monthly census was carried out in order to assess the migrations of fishermen inside and outside the estuary. The 11 villages sampled represent between 60 and 80\%, according to the season, of the fishing population living and working in the estuary.

- Fishing effort was computed from a daily survey of the activities of 10 fishing units randomly chosen in the same village; 1150 questionnaires were collected each month, 33\% from shrimpers and $67 \%$ from fishermen targeting fish.

- Estimates of fishing effort, total catch, fish composition and length structure were collected from returning fishing canoes sampled at the landing stage with an average of 625 surveys being made per month. In all, 3200 surveys were carried out at the mouth, 3000 in middle sector and 1300 upstream.

Fish landed were sorted by species when possible (70\% of sampled species) or by genus $(30 \%)$ when field identification was difficult. Then for each taxon, individuals were counted and weighed and 10 were measured. All species combined, more than 130000 fishes were measured during the monitoring of the fisheries (Table 1).

\subsection{Statistical analysis}

In order to understand the abundance distribution of the main fish species in the Gambia estuary, the 55 fish and crustacean species observed in canoe landings have been grouped into ecological classes. The composition of the assemblages was discussed using the species classification proposed by Albaret (1999), which defines eight bio-ecological categories ordered on two gradients from a central point, the strictly estuarine species (Es). The gradient of marine affinity comprises four categories: the estuarine species from marine origin (Em), the marine estuarine species (ME), the marine species accessory in estuaries $(\mathrm{Ma})$ and the marine species occasional in estuaries (Mo). The gradient of freshwater affinity comprises the estuarine species from freshwater origin (Ec), the freshwater species with estuarine affinities (Ce), and the freshwater species, occasional in estuaries $(\mathrm{Co})$. Four of these categories (Ec, Es, Em and ME) compose the fundamental lagoon and estuarine community.

The catch per trip of the main fishing gears in the Gambia estuary was presented as a scatter plot of data as function of both month and spatial distribution (mouth, middle and upstream estuary). As these values are both dependant on natural variability of the ecosystem and availability of fish, their values are widely distributed (standard deviation equivalent to mean). As a consequence, for comparison purpose, we decided to smooth the curve along the points. A lowess (locally weighted regression) curve (Cleveland 1979) was fitted by least squares ("Gaussian") to the data to summarize the distribution patterns. The smooth curve locally minimizes the variance of the residuals or prediction error. Only the points in that vicinity determine the curve value at each particular location along the $x$-axis. The span (i.e. the value between 0 and 1 controlling the amount of smoothing) was fixed to 0.5 . The calculation and graph was done using the $\mathrm{R}$ statistical language. In addition, as the variances of the different gear samples were not homogeneous, a non parametric test was realised. A Kruskal-Wallis test for several independent samples was used that is equivalent with a one way ANOVA for normal quantitative data (Scherrer 1984). A cross analysis was performed testing both the effect of gears and those of spatial and temporal distributions. 
Fishing effort data and fish landing data collected by the survey network were extrapolated to each of the three areas of the estuary using descriptors of the fishery, such as the number of fishing units classified as shrimpers or fish fishermen, which had been estimated during a preliminary census of the whole estuary (Fisheries Department 1997). The extrapolation was given by:

$$
C=\Sigma_{Z}^{1} \Sigma_{G}^{1} \Sigma_{M}^{1}[U P \cdot J(s / p \cdot j) \text { CPUE }]
$$

$C=$ Total catches, $U P=$ Number of fishing units in the sector, $J=$ Number of days of the month, $s=$ Number of trips during the sampling period, $p=$ Number of sampled fishermen, $j=$ Number of sampled days, CPUE = Catch per unit effort for one fishing gear in one area for one month, $Z=$ Number of zones, $G=$ Number of types of gears, $M=$ Number of months.

The extrapolation was made in order to assess the total shrimps and fish catches in the estuary. It could be done in this way even with migration of fishermen, because the monitoring of the fishery produced monthly information about fishermen census, fishing activities, CPUE and catch per species for each fishing gear in the three zones of the Gambia estuary.

\section{Results}

\subsection{Fishing places and fishing units migration}

The annual census of the Gambia estuary (Fisheries Department 1997) counted 106 fishing villages. Among the latter, $46 \%$ have less than 5 canoes, $90 \%$ less than 15. As most of the total canoes (900) were non-motorized (89\%), it clearly appeared that fishing activities were concentrated in a few commercial places, the others conducting subsistence fishery activities.

Our monthly census of 11 sampled villages (Fig. 2), showed that the number of fishing units was quite stable throughout the year in some villages (Pirang, Bintang, etc.), decreasing from April to August in some villages located downstream in the estuary (Barra, Toubakolong, Albreda), and at the same time increasing in villages located upstream in the estuary (Tendaba, Jappeni, Kanikunda). These migrations mainly concerned shrimpers and were dependant on water salinity and shrimp abundance: 1) from March to August, this number in the 11 sample villages ranged from 331 to 217,2 ) the number of shrimp fishing units in the estuary varied from 432 in December 1999 to 596 in June 2000. In fact, most of the shrimpers are Senegalese people settled in the Gambia in big villages at the mouth of the estuary, moving from downstream to upstream when shrimp abundance varies. These shrimpers are reinforced by migrant Senegalese shrimpers, moving to the different estuaries of the sub-region (Sine Saloum, Gambia, Casamance, Guinea) and working in the Gambia estuary for shorter periods of three months concentrated on high shrimp abundance.

\subsection{Fishing effort}

The Gambia estuary fisheries are typically multi-gear. Some thirty-eight different types of fishing gear and capture methods have been described. The main types were stownets (fixed nets for shrimps), drift nets, gillnets, surrounding nets, cast nets, handlines and longlines. Among the drift nets, surrounding nets and gill nets, $40 \%$ of the nets were large mesh ones ( $>50 \mathrm{~mm}$ side) and $55 \%$ were medium mesh ones (30 $\mathrm{mm}<$ side $<50 \mathrm{~mm}$ ). Only $5 \%$ of the nets were small mesh ones (side $<30 \mathrm{~mm}$ ). All the gears were adapted to the habitat characteristics of the estuary, to the fish species and to the targeted fish sizes as many artisanal fisheries in developing countries (Welcomme 1985; Ecoutin et al. 1994). Some different gears could be used during one fishing trip as it was generally for stownets and lines.

According to the one-year survey carried out in the estuary, the percentage of daily fishing trips of stow nets (53\%) was generally higher than those for other gears: lines $(17 \%)$, drift nets $(17 \%)$, gill nets $(7 \%)$, surrounding nets $(6.5 \%)$, cast nets $(2 \%)$. The percentage for stow nets was high and stable for all the seasons and in the three areas. For the other gears, the percentage was rarely greater than $10 \%$ and varies according to area. For this reason, shrimp activities can be considered as professional ones (full time activity) whereas hooks (longlines and handlines combined) and nets are only occasional ones (part time activity).

On an annual basis (Table 2), considering the number of shrimp units (500) and fish units (300) and their daily activity, the fishing gear most frequently used were stownets $(66 \%)$ and large and medium mesh gill nets $(17 \%)$. In addition, fishing activities decreased from the mouth (62\% of fishing trips) to the middle area (26\%) and upstream area (12\%).

Although fish communities varied strongly during the dry and wet seasons in terms of diversity, abundance and species composition (Albaret et al. 2004), fish fishing activities did not reflect this natural variability because fish fishermen mainly targeted top predators. As a consequence, fish effort targeting fish appeared to be quite stable both in spatial distribution and intensity (3835 fishing trips during the wet season versus 4400 during the dry season). As a first conclusion, fishing activities in the Gambia estuary are highly specialized and mainly targeting shrimps.

\subsection{CPUE}

First analysis of the average annual catches per fishing trip shows that catches exceed $23 \mathrm{~kg}(S D=27 \mathrm{~kg})$ for all gear combined. The values ranged from more than $35 \mathrm{~kg}$ for surrounding nets, drift nets and cast nets to $23 \mathrm{~kg}$ for hooks and gill nets (Fig. 3). The case of stownets must be considered separately as catches were composed both of shrimp and fish: small fish mainly caught with stow nets were discarded and large fish provided from handlines used by shrimpers when waiting for the turn of the tide. Although this CPUE is the lowest registered $(14 \mathrm{~kg})$, the $30 \%$ of shrimp that composed the capture gives a high trading value to the catch and make profitable the use of stownets.

A seasonal variation in catch (fish and shrimp) existed for all the three zones and all the gears (Fig. 3), even if catch per trip in the mouth seemed to be more regular. The CPUE were greater between September and March in the middle area, and from January to April in the upstream area. These values are 


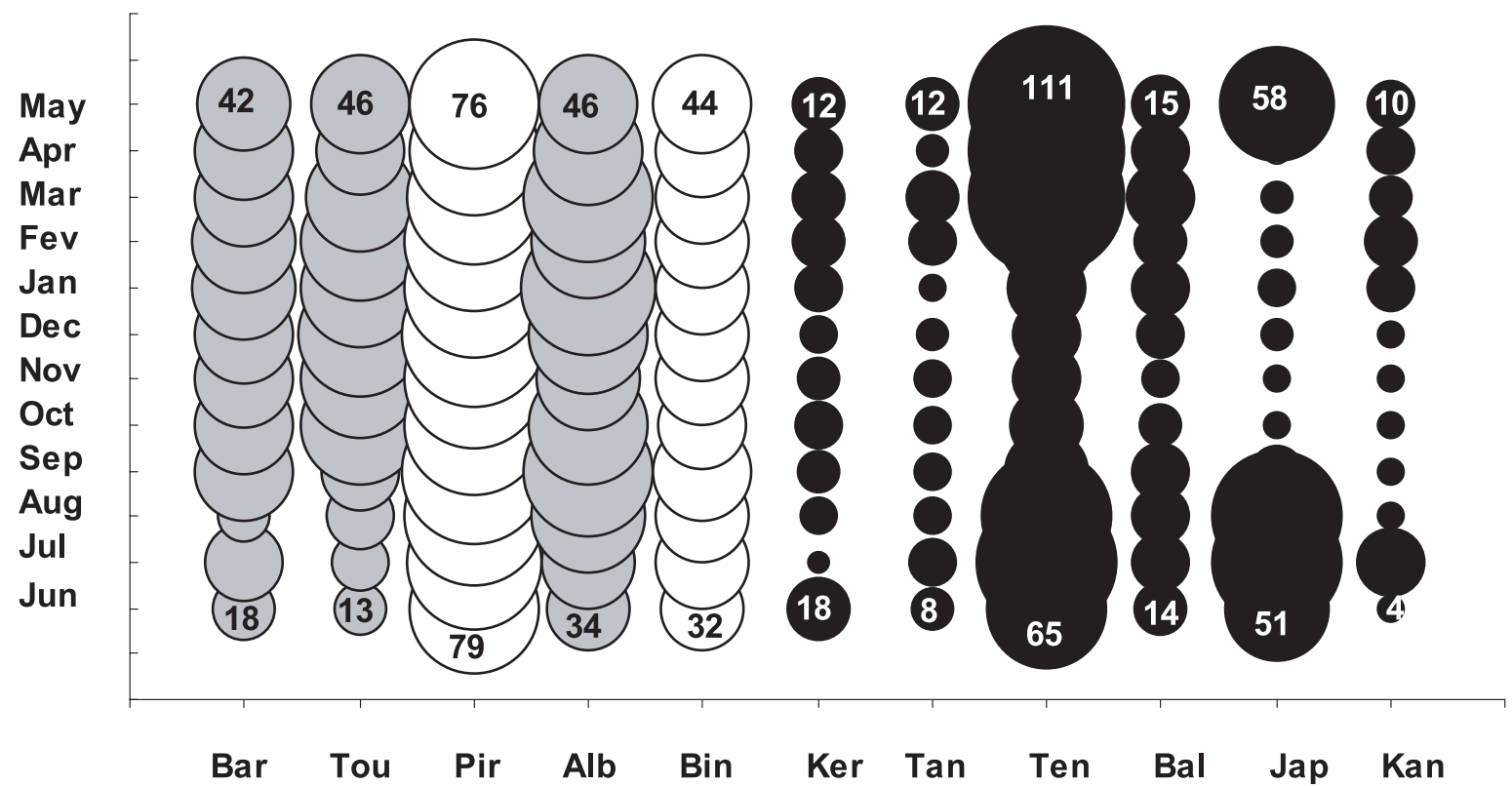

Fig. 2. Monthly census (number of fishing units) in the sampled villages of the Gambia River from June 2001 to May 2002 . The number of units per village was stable (white), decreasing from April to August (grey), increasing at the same time (black).

Table 2. Spatial distribution of fishing effort (number of fishing trips) for the fishing units sampled during the one year survey.

\begin{tabular}{|c|c|c|c|c|c|}
\hline Fishing gear & Code & Mouth & Middle & Upstream & $\%$ \\
\hline Cast nets & CastN & 4 & 75 & 107 & 0.7 \\
\hline Stownets & StowN & 12014 & 3132 & 1468 & 66.3 \\
\hline Drift nets large mesh & & 57 & 1121 & 427 & \\
\hline Drift nets medium mesh & DriftN & & 207 & 426 & 9.0 \\
\hline Drift nets small mesh & & & & 4 & \\
\hline Gill nets large mesh & & 85 & 260 & 25 & \\
\hline Gill nets medium mesh & GillN & 462 & 23 & 74 & 3.7 \\
\hline Gill nets small mesh & & & 1 & & \\
\hline Surrounding nets large mesh & & 652 & 9 & & \\
\hline Surrounding nets medium mesh & SurN & 5 & 281 & 194 & 4.7 \\
\hline Surrounding nets small mesh & & & 13 & 14 & \\
\hline Longlines & & 262 & 1338 & 274 & 7.5 \\
\hline Handlines & & 2019 & & 2 & 8.1 \\
\hline Total & & 15560 & 6460 & 3015 & \\
\hline
\end{tabular}

significantly different as attested by a cross Kruskal-Wallis test on estuarine zones, seasons and gears (Table 3 ).

Concerning shrimp, 2600 canoes were sampled in the three zones during the three seasons. CPUE values ranged from $3.1 \mathrm{~kg} \mathrm{trip}^{-1}$ during the fall in the mouth to $10.9 \mathrm{~kg}$. trip $^{-1}$ during low water in upstream area. According to Figure 4, Penaeus notialis was concentrated in the mouth and middle areas during the whole year (with low abundances during the fall) whereas they were very abundant in the upstream area only during the low water season and at the beginning of the flow (May to August) when saline water moved upstream. The values per season for the three areas are significantly different as attested by a Kruskal-Wallis test, but only for the low water season when they are calculated per area.

Catch per species showed that the fish landings were composed of 55 species (both fish and crustaceans), of which 16 species accounted for $90 \%$ of total CPUE (Table 4). The most abundant species was Polydactylus quadrifilis, but Arius spp. and Penaeus notialis were also very abundant. In terms of ecological classes, estuarine species of marine origin dominated all three sectors although estuarine species of freshwater origin and freshwater species were present in middle and upstream sectors during the wet season. Twenty-nine species were of marine origin, twenty-one were estuarine, and only five were of freshwater origin. Occasional marine species were recorded at the mouth of the estuary and freshwater species mainly in the upstream area. All other species (Marine accessory, Marine estuarine, Estuarine marine, Estuarine) were recorded at all landing sites depending on season and salinity.

The analysis of CPUE values for individual species (Table 5) showed that the different fishing techniques were highly specialized and targeted mainly one species: Sarotherodon melanotheron for cast nets (65\%), Penaeus notialis for stow nets (47\%), Polydactylus quadrifilis for large 

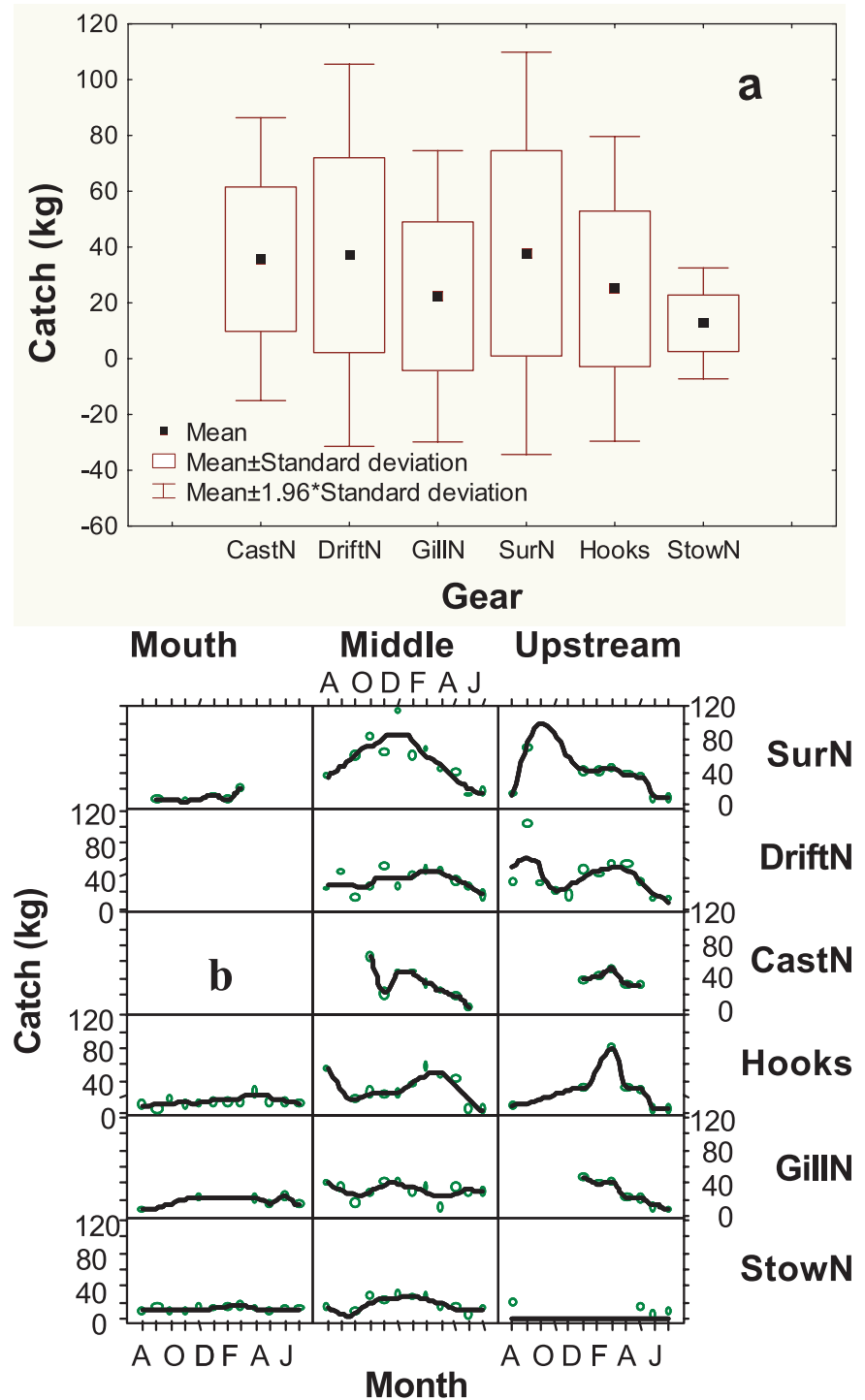

Fig. 3. (a) Mean annual catch and (b) spatial and temporal variability of catch (using the lowess curve in Cleveland 1979) of the artisanal fisheries of the Gambia estuary. Catch include shrimp and fish.

(67\%) and medium mesh (59\%) drift nets, Cynoglossus spp. for large (33\%), medium mesh (26\%) gillnets and large mesh surrounding nets (40\%), Arius spp. for handlines (33\%) and longlines $(50 \%)$. For each fishing technique, one to three species accounted for $70-80 \%$ of catches.

\subsection{Total catches}

In 2001-2002 the total estimated catch for the artisanal fishery was 2350 tonnes. Stow nets were the most productive gear with respectively 550 and $600 \mathrm{t}$ of shrimp and fish per year. They accounted for $50 \%$ of the total production, the other half production being provided mainly by drift nets $(22 \%)$, hooks $(15 \%)$, surrounding nets $(5 \%)$, gillnets $(6 \%)$ and cast nets $(2 \%)$.

The total catch was divided into $1800 \mathrm{t}$ of fish and $550 \mathrm{t}$ of shrimps. Fish catch was similar and equivalent to $650 \mathrm{t}$ in

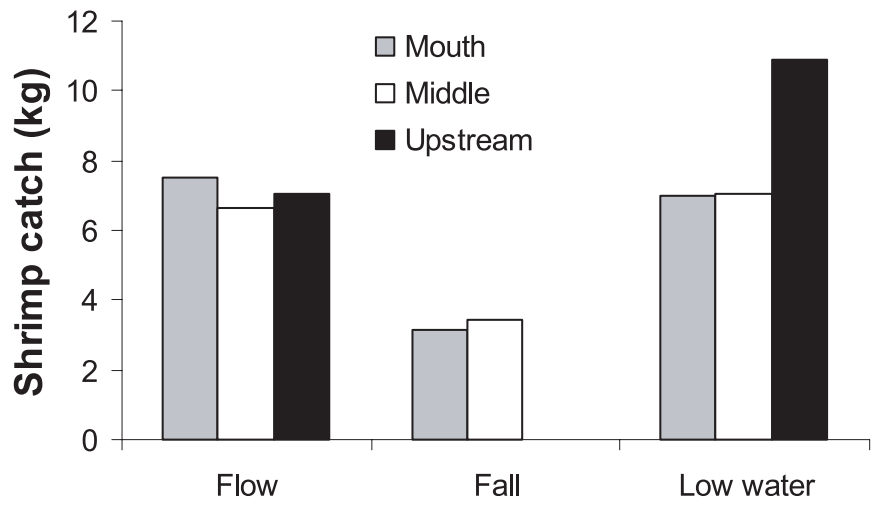

Fig. 4. Spatial and temporal distribution of shrimp catch $(\mathrm{kg})$ per fishing trip for the estuarine artisanal shrimp fishery, 2001-2002.

Table 3. Results of a cross Kruskal-Wallis test on spatial and seasonal catch per trip (all gears combined) and between gears (code in Table 2) independently of estuarine zones and hydrological seasons. $H_{0}=$ the sample group is homogeneous. Table gives the value of $H_{c}$ and one asterisk represents a probability lower than 0.05 , two asterisks a probability $<0.01$ (alternative hypothesis $\mathrm{H} 1$ of disparity for at least one population is accepted).

\begin{tabular}{|l|c|c|c|c|c|}
\hline & Flow & Fall & $\begin{array}{c}\text { Low } \\
\text { Water }\end{array}$ & & \\
\hline Mouth & $20^{*}$ & $29^{* *}$ & $69^{* *}$ & & \\
\hline Middle & $83^{* *}$ & $111^{* *}$ & $354^{* *}$ & & \\
\hline Upstream & $34^{* *}$ & $11^{*}$ & $116^{* *}$ & & \\
\hline & & & & & \\
\hline CastN & DriftN & GillN & Hooks & StowN & SurN \\
\hline $44^{* *}$ & $98^{* *}$ & $139 * *$ & $341^{* *}$ & $170^{* *}$ & $208 * *$ \\
\hline
\end{tabular}

the mouth and middle sectors of the estuary. Shrimp catch was higher (360 t) at the mouth where fishing activities can continue throughout the year than in the middle area $(78 \mathrm{t})$. The upstream sector was less productive for fish (460 t), but provides a seasonal shrimp production equivalent to middle sector (94 t). On an estuary scale, shrimp catch was higher from April to September while fish production was better from January to May (Fig. 5).

Two taxa represented half of fish landings: Polydactylus quadrifilis (26\%) and Arius spp. (20\%), which are mainly caught by handlines, longlines and drift nets. According to Albaret et al. (2004), among Arius two species were abundant: A. latiscutatus and A. parki, the third one A. heudeloti being less frequent. Then, Pseudotolithus elongatus accounted for $9 \%$ of fish catches and the six following taxa ranged from 3 to 4\%: Liza grandisquamis, Pentanemus quinquarius, Ethmalosa fimbriata, Cynoglossus spp., Ilishia africana and Pseudotolithus senegalensis (Fig. 6).

\subsection{Catch lengths}

Analysis of the shrimp lengths (15000 individuals measured during one annual cycle) showed significant differences between the three geographical areas (ANOVA, $p<0.0001$ ). Large average lengths were registered at the mouth (mean $\pm S D$, 
Table 4. Annual distribution limits of fish and shrimp species recorded in the catch of the estuarine artisanal fishery (expressed as number of individuals caught: * rare, $* *$ frequent, $* * *$ abundant; Cat: ecological categories described in the text). Percentage in brackets represents the species composition of annual CPUE $\left(\mathrm{kg}\right.$ fishing trip $\left.{ }^{-1}\right)$ for the main species.

\begin{tabular}{|c|c|c|c|c|c|c|c|c|c|c|c|c|}
\hline \multirow[b]{2}{*}{ Species } & \multirow[b]{2}{*}{ Cat } & \multicolumn{4}{|c|}{ Mouth } & \multicolumn{4}{|c|}{ Middle } & \multicolumn{3}{|c|}{ Upstream } \\
\hline & & 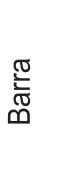 & $\begin{array}{l}\text { 음 } \\
\text { 응 } \\
\text { 융 } \\
\text { 음 } \\
\text { 음 }\end{array}$ & 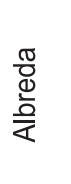 & 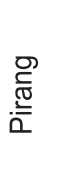 & 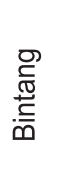 & 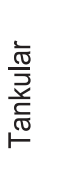 & 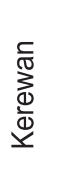 & $\begin{array}{l}\frac{\pi}{0} \\
\frac{\pi}{\pi} \\
\frac{0}{0} \\
\stackrel{0}{-}\end{array}$ & $\begin{array}{l}\stackrel{\circ}{\text { D }} \\
\overline{\bar{D}} \\
\text { Ф }\end{array}$ & 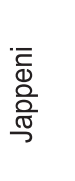 & 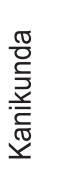 \\
\hline Ablennes hians & Mo & & & & * & * & * & & & & & \\
\hline Carcharhinus spp. & Mo & * & & & * & $* *$ & * & $* *$ & ** & * & * & * \\
\hline Psettodes belcheri & Mo & * & & & & & & & & & & \\
\hline Cephalopholis nigri & Mo & * & & & & * & & & & & & \\
\hline Alectis alexandrinus & Mo & * & & & & & & & & & & \\
\hline Chaetodipterus lippei & Ma & & * & * & * & * & * & & & & & \\
\hline Lagocephalus laevigatus & $\mathrm{Ma}$ & ** & * & ** & ** & * & * & & & & & \\
\hline Pentanemus quinquarius (1.5\%) & $\mathrm{Ma}$ & & $* * *$ & 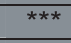 & $\star \star \star *$ & $* * *$ & $* * *$ & & $* * *$ & & ** & \\
\hline Pseudotolithus senegalensis (2.2\%) & Ma & *** & ** & *** & *** & ** & ** & ** & ** & *** & ** & ** \\
\hline Arius spp. (14.5\%) & $\mathrm{ME}$ & *** & *** & *** & *** & *** & *** & *** & *** & ** & *** & ** \\
\hline Elops lacerta & $\mathrm{ME}$ & ** & * & * & ** & ** & ** & 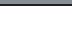 & 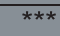 & * & ** & * \\
\hline Brachydeuterus auritus & $\mathrm{ME}$ & & & & & & * & & & & & \\
\hline Caranx senegallus & $\mathrm{ME}$ & * & & & * & * & * & ** & ** & * & * & \\
\hline Caranx hippos & $\mathrm{ME}$ & ** & * & * & & * & * & ** & * & * & * & * \\
\hline Drepane africana & $\mathrm{ME}$ & ** & ** & * & $* * *$ & $* * *$ & ** & ** & ** & & & \\
\hline Galeoides decadactylus & $\mathrm{ME}$ & $\star \star * *$ & * & ${ }^{*}$ & $* * *$ & $* * *$ & 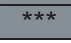 & $\ldots$ & * & & & \\
\hline Eucinostomus melanopterus & $\mathrm{ME}$ & * & * & * & & & & & & & & \\
\hline Pseudotolithus brachygnathus & $\mathrm{ME}$ & $\star * * *$ & ** & ** & $* *$ & $* * *$ & *** & ** & * & ** & & * \\
\hline Epinephelus aeneus & ME & ** & ** & * & * & * & * & - & * & & & \\
\hline Polydactylus quadrifilis (32\%) & $\mathrm{ME}$ & $\overline{t *}^{* *}$ & * & ** & * & $\bar{*}^{* * *}$ & $\overline{* \star * \star}^{* \star *}$ & $\star \star \star * *$ & 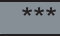 & $\star_{\star \star * *}$ & $\star \star \star *$ & **** \\
\hline Pseudotolithus typus (1.2\%) & $\mathrm{ME}$ & ** & * & ** & *** & *** & *** & * & * & * & & \\
\hline Rhinobatos spp. & $\mathrm{ME}$ & * & & & & & - & & * & & & \\
\hline Sardinella maderensis & $\mathrm{ME}$ & & & & & & ${ }_{* \star *}^{* \star}$ & & & & & \\
\hline Sphyraena spp. (2.1\%) & ME & * & & * & * & * & * & ** & * & ** & * & ** \\
\hline Trichiurus lepturus & $\mathrm{ME}$ & & * & * & ** & * & ** & & * & & & \\
\hline Umbrina canariensis & $\mathrm{ME}$ & * & & & & & & & & & & \\
\hline Citarichthys stampflii & Em & & & & * & * & ** & & & & & \\
\hline Cynoglossus spp. (4.5\%) & Em & $* * *$ & * & ** & ** & * & ** & * & *** & *** & & * \\
\hline Dasyatis spp. & $\mathrm{Em}$ & ${ }^{\star *}$ & * & * & * & ** & * & * & ** & * & * & \\
\hline Ethmalosa fimbriata (3.4\%) & Em & ** & & ** & $* * *$ & *** & *** & *** & *** & *** & **** & *** \\
\hline Ilisha africana (1.2\%) & Em & & $\star \star * *$ & *** & *** & $* * *$ & $\star * * *$ & & *** & & ** & \\
\hline Liza dumerili & Em & & & & $* *$ & $* * *$ & $\star * *$ & & & & & \\
\hline Liza falcipinnis & Em & & & & & & & *** & $* * *$ & & & $* * *$ \\
\hline Liza grandisquamis (4.8\%) & Em & & ** & ** & $* * *$ & *** & *** & *** & *** & *** & *** & *** \\
\hline Mugilidae (1.2\%) & Em & & ** & ** & *** & $\star \star * *$ & *** & ** & *** & ** & ** & ** \\
\hline Pseudotolithus elongatus (5.4\%) & Em & $* * *$ & $\star \star \star \star *$ & *** & 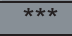 & *** & *** & *** & *** & *** & *** & *** \\
\hline Pomadasys jubelini & Em & & * & & ** & & * & ** & * & * & 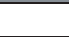 & \\
\hline Plectorhinchus macrolepis & Em & $* *$ & & * & * & * & * & ** & * & ** & ** & ** \\
\hline Pomadasys spp. & Em & *** & ** & ** & *** & ** & *** & ** & * & * & * & ** \\
\hline Pomadasys perotaei & Em & ** & ** & * & & * & & * & & * & & \\
\hline Trachinotus teraia (1.7\%) & Em & ** & * & * & * & * & ** & *** & * & *** & * & ** \\
\hline Gerres nigri & Es & * & & & & & 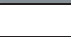 & 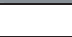 & & & & \\
\hline Monodactylus sebae & Es & & * & * & * & $* * *$ & $\star \star \star *$ & $* * *$ & $\star * *$ & * & $* * *$ & $\star *$ \\
\hline Tilapia guineensis & Es & & * & & & & & & & & & \\
\hline Sarotherodon melanotheron (3\%) & Es & ** & & * & ** & * & ** & $* * *$ & $* * *$ & *** & $* * * *$ & $* * *$ \\
\hline Hemichromis fasciatus & Ec & & & & & & & *** & & 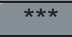 & & *** \\
\hline Synodontis gambiensis & $\mathrm{Ce}$ & & & & & & & & & * & *** & * \\
\hline Chrysichthys spp. (2.1\%) & Co & & & & & ** & ** & $* * *$ & $* * *$ & ** & *** & $* * *$ \\
\hline Clarias spp. & Co & & & & & & & ** & * & * & 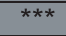 & *** \\
\hline Heterotis niloticus & Co & & & & & & & & & & & $* *$ \\
\hline Hepsetus odoe & Co & & & & & & & * & * & & * & $* * *$ \\
\hline & & & & & & & & & & & & \\
\hline Callinectes sp. & & & & & **** & *** & $\overline{* \star *}^{* *}$ & & & & & \\
\hline Penaeus monodon & & * & * & * & * & * & * & & & & & \\
\hline Penaeus notialis (9.1\%) & & & * & $\star *$ & $* *$ & ** & * & & * & * & & ** \\
\hline
\end{tabular}




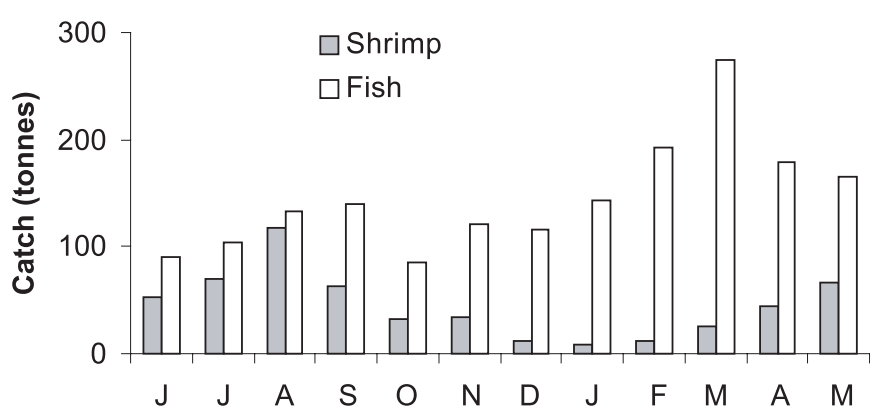

Fig. 5. Monthly distribution of annual catch (shrimp and fish) of the artisanal fisheries of the Gambia estuary, 2001-2002.

Table 5. Percentage of catches for the main species (code given in Table 1) caught by the gear used in the Gambia estuary (the difference to $100 \%$ is composed on numerous species which individual percentage is lesser than $10 \%$ ).

\begin{tabular}{lcccccc}
\hline & Sme Pdu & Ari Poq Cyn Pom Lgr \\
\hline Cast nets & 65 & & & & 11 \\
Stownets & & 47 & 14 & & & \\
Drift nets large mesh & & & & 67 & & \\
Drift nets small mesh & & & 59 & & \\
Gill nets large mesh & & & 24 & 33 & \\
Gill nets medium mesh & & & 23 & 26 & \\
Surrounding nets large mesh & 20 & & 40 & \\
Surrounding nets medium mesh & & & 11 & & & 32 \\
Handlines & & 33 & & & 11 & \\
Longines & & 50 & 32 & & & \\
\hline
\end{tabular}

$121 \pm 31 \mathrm{~mm})$ and upstream areas $(136 \pm 27 \mathrm{~mm})$ and smaller ones in middle area $(113 \pm 31 \mathrm{~mm})$. The differences between the hydrological seasons were not significant at the contrary of the interactions between hydrological seasons and zones $(p<0.0001)$ : shrimps were present and large in upstream area only during the low water season $(133 \pm 29 \mathrm{~mm})$ and the beginning of the fall $(137 \pm 26 \mathrm{~mm})$. In the middle area, the fall $(109 \pm 27 \mathrm{~mm})$ and the flow $(113 \pm 29 \mathrm{~mm})$ were mainly characterized by small shrimps. Last, in the mouth the average length of shrimps were quite stable during all the year (values ranging from 120 to $124 \mathrm{~mm}$ ).

For fish, the average length for the first sixteen species (90\% of total fish landings) was $295 \pm 175 \mathrm{~mm}$. The species with the highest maximum length had a high average catch length: Polydactylus quadrifilis $(639 \pm 299 \mathrm{~mm})$, Arius spp. $(306 \pm 66 \mathrm{~mm})$, Pseudotolithus elongatus $(243 \pm 52 \mathrm{~mm})$, Cynoglossus spp. (417 $\pm 75 \mathrm{~mm})$ and Pseudotolithus senegalensis $(359 \pm 156 \mathrm{~mm})$. According to these observations, fishing for fish is targeting large fish with high average lengths (Fig. 7).

\section{Discussion}

\subsection{Spatial distribution and exploitation of shrimps}

According to Lhomme and Garcia (1984), post larval recruitment of Penaeus notialis in the Sine Saloum, Gambia and

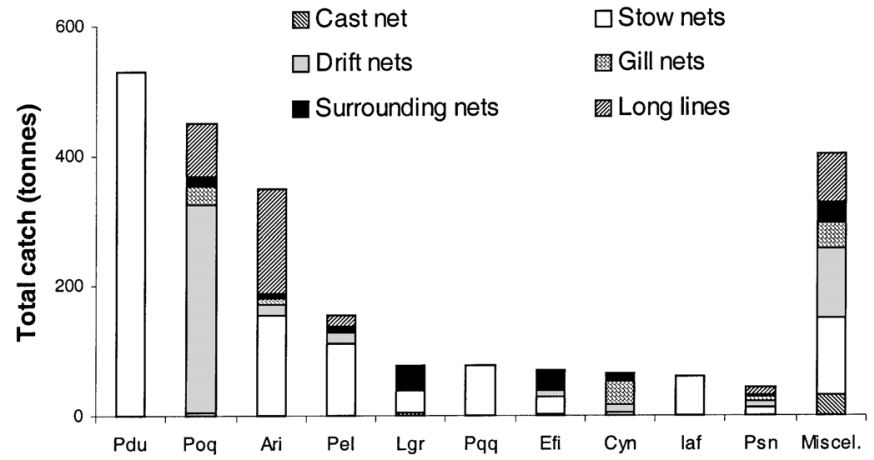

Fig. 6. Species distribution (code in Table 1) of annual catch (including shrimps) of the artisanal fisheries of the Gambia estuary, 2001-2002.

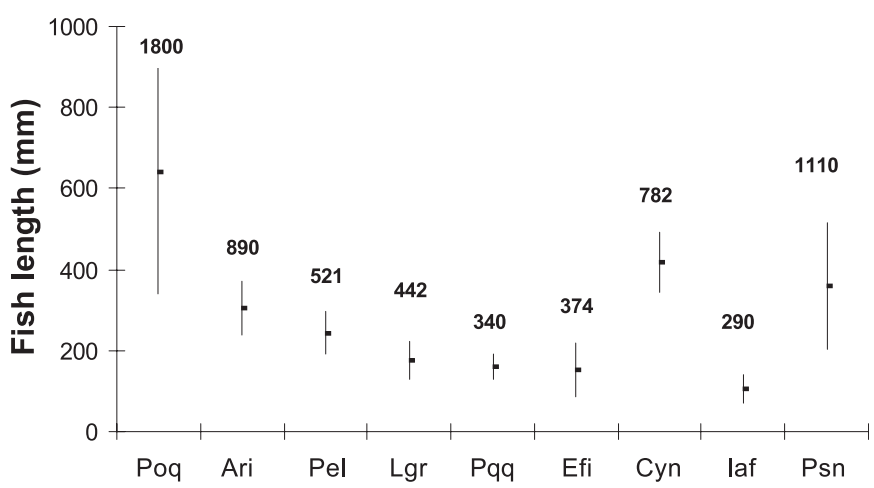

Fig. 7. Catch length (average and standard deviation) of the main fish species (code in Table 1) caught in the Gambia estuary. Numbers in bold character represents the observed maximum length.

Casamance estuaries depends on adult stocks located in the sea from the frontier between Senegal and Guinea Bissau. Juveniles and sub-adults live in the estuaries where their length of stay is around 3 months (Lhomme 1981) but mainly depends on water current and salinity (Le Reste 1984; 1992; 1994): values of 30 psu favour a long stay until an average length of $13 \mathrm{~cm}$. In the Gambia estuary, salinity is always favourable in the mouth for the occurrence of shrimp and fishing activities are possible throughout the year, but shrimp length is either small or large depending on the season and water currents. In the middle area, salinity and currents are always favourable, even if they are not optimum for shrimps. This is an intermediate situation where yield and shrimp length allow the fishery to be permanent. In upstream areas, shrimp resources vary greatly from zero abundance during the wet season to high abundance during the dry season. As a consequence there is no shrimp activities during the wet season but in contrast, an incoming migration of Senegalese fishermen during the dry season, with the certainty of obtaining high yields of large shrimps.

According to previous studies (Leendertse 1995) and using comparative analysis with some estuaries of the sub-region, it is possible to conclude that shrimp fishing effort in the Gambia is still at a sustainable level for three main reasons:

1) The number of shrimpers is quite low: 430 during the wet season and 600 during the dry season when it was 600 in 
Table 6. Characteristics of some estuaries in the South Senegal region (Guiral et al. 1999) and quantitative data on fishing activities (adapted from Ecoutin et al. 1999).

\begin{tabular}{lccc}
\hline & Saloum & Gambia & Casamance \\
\hline Species richness in the estuary & 103 & 52 & 91 \\
River length $(\mathrm{km})$ & 130 & 1200 & 350 \\
Watershed area $\left(\mathrm{km}^{2}\right)$ & 29720 & 77000 & 14000 \\
Average discharge $\left(\mathrm{m}^{3} \mathrm{~s}^{-1}\right)$ & 0 & 139 & 2 \\
Estuary length $(\mathrm{km})$ & 130 & 230 & 220 \\
Maximum salinity (psu) & 100 & 33 & 172 \\
Type of estuary (Blaber 2000) & Inversed Ria & Normal open & Inversed Ria \\
Villages & 68 & 106 & 292 \\
Fishermen & 6619 & 82300 & 9450 \\
Canoes & 1000 & 2350 & 2115 \\
Total Catch per year (t) & 8000 & 2.9 & 14000 \\
Catch/Canoe (t) & 8 & 2 & 6.6 \\
Fishermen/Canoe & 6.6 & & 4.5 \\
\hline
\end{tabular}

the Casamance estuary in 1967 and 2400 in 1976 (Le Reste 1986).

2) Shrimp fishing is only based on the use of $13 \mathrm{~mm}$ mesh stownets, catching medium size juveniles (average length of $121 \mathrm{~mm}$ ) in the central course of the river when in the Casamance river and the Sine Saloum, shrimpers also use drift nets and baskets (killis) trawled by two men near the banks, mainly targeting small shrimps (Bousso 1996).

3) The annual shrimp catch is estimated to be $550 \mathrm{t}$ compared with $1600 \mathrm{t}$ in the Casamance estuary for the period 19861991 (Le Reste 1994).

As an early diagnosis fishing effort seems to be sustainable but it may be increasing because of political instability in Guinea Bissau and Casamance regions which led to Senegalese fishermen leaving to find safer areas. In addition, irrespective of fishing in the estuarine area, the shrimp stock is dependent on fishing effort applied to adult stages in the sea (Garcia 1996). This is worrying because overfishing is yet a reality in marine waters leading the Senegalese authorities to establish a two months biological rest in order to preserve fish resource (Chavance et al. 2004).

\subsection{Current state of fish fishing in the Gambia estuary}

Fishing for fish in the Gambia estuary is based on the use of very selective gears (medium mesh nets and hooks) that target large fishes. The daily rate of use of these fishing gears is low as is the number of fish fishing units (300). Consequently, the effective fishing effort is low in comparison with that of stownets. The CPUE is high for this type of artisanal fishing and especially for gear targeting large fish. Fishing activities are mainly concentrated on a few species that are commercially profitable: Polydactylus quadrifilis, Arius spp., Cynoglossus spp. Annual catches of 1800 t are relatively low for such a large estuary and average catch lengths are high ranging from 300 to $600 \mathrm{~mm}$ for the main species captured. These findings suggest low levels of fish exploitation. When comparing these values with the other sub-regional estuaries, it appears that total catch in the Senegal basin was estimated to be 18 500-25900 t year $^{-1}$ in 1974 (Reizer 1974) and 8000-10000 tyear $^{-1}$ in the late 1980s (Diouf et al. 1991;
Bousso 1996). In the Sine Saloum, from 1990 to 1993 fish production was estimated to be $10000 \mathrm{t}$ per year (Bousso 1996) and $14000 \mathrm{t}$ in the Casamance estuary in 1984 (Diadhiou et al. 1986). Fishing parameters in the Gambia estuary (Table 6) are always clearly lower than those recorded in the other subregional estuaries: fewer fishermen of all socio-economical classes, fewer fishing units, fewer total catches and even less annual catch per canoe. This last point can be explained by 1) a high specialisation of fishermen on shrimp fishing (lower yield) and by 2) the low level activity of the other ones only fishing for subsistence purposes. As a consequence, even if CPUE are high, the annual catch per canoe is relatively low.

\subsection{Effects of foreign demand on structuring estuarine fisheries in the Gambia}

At the beginning of the 1980s, fishing was mainly conducted by small local fishing units (380 fishermen) and foreign units accounted for only $15 \%$ of the total (equivalent to nine companies targeting shrimps and using less than 200 stownets) (Fisheries Department 1983). Twenty years later, estuarine fishing is mainly carried out by about a hundred fishing companies involving 800 fishermen (more than $80 \%$ of them foreigners) using more than 1750 stownets. As a result of the globalisation of fish markets, in 2002 the Gambia exported $150 \mathrm{t}$ of shrimp to West Africa and $350 \mathrm{t}$ to Europe. This globalisation was expressed by the appeal of European markets and in this case, the differences between the local and European prices of shrimp led to a re-allocation of fishing effort to valuable species: the cost of one $\mathrm{kg}$ of shrimp is three time higher (30 dalasis) than those of fish. As a consequence, the fishery has become a quasi mono-exploitation of shrimp for exporting.

\section{Conclusion}

The consequences of shrimp specialization in the Gambia estuary for fish exploitation are multiple. The period before shrimp exploitation in the estuary was characterised by the trade in processed fish to local and sub-regional markets, 
whereas the present period is mainly characterised by the attractive flow of fresh shrimps from the freezing factories of Banjul ( $87 \%$ of fresh products and $70 \%$ of total trade products). Mono exploitation has led to a re-allocation of fishing effort on shrimps and has prioritised European consumers rather than local ones. This has led to a change in the traditional valuation of fish: fresh shrimp has now replaced artisanal processing (drying, smoking) of fish. It really appears that during the last two decades, mono-exploitation of shrimp in the Gambia estuary has strongly affected and reoriented estuarine fisheries leading to an underexploitation of fish resource.

In addition, when thinking about the real problem of bycatch and discards, the best example is often given by shrimp trawling which is characterized by the highest ratio of bycatch to shrimp catch, generally from 5 to $10: 1$. This worrying angle has not been studied in this paper for the artisanal shrimp fisheries although many discards have been registered. Even if discards, when referring to fixed nets, seem to be lower than for trawlers, the quantities are consequent and this particular problem would deserve to be examined in order to correctly assess the impact of the shrimp fisheries on fish resource.

Acknowledgements. This study was conducted as a joint program between IRD (UR RAP, Dakar) and the Gambian Fisheries Department.

\section{References}

Albaret J.J., 1987, Les peuplements de poissons de la Casamance (Sénégal) en période de sécheresse. Rev. Hydrobiol. Trop. 20, 291-310.

Albaret J.J., 1999, Les peuplements des estuaires et des lagunes. In: Lévêque C., Paugy D. (Eds.), Les poissons des eaux continentales africaines : Diversité, écologie, utilisation par l'homme. Edition de l'IRD, Paris, pp. 325-349.

Albaret J.J., Simier M., Darboe F.S., Ecoutin J.M., Raffray J., Tito de Morais L., 2004, Fish diversity and distribution in the Gambia estuary, West Africa, in relation to environmental variables. Aquat. Living Resour. 17, 35-46.

Blaber S.J.M., 2000, Tropical estuarine fishes, Ecology, Exploitation and Conservation. Fish and Aquatic Resour. Ser. 7, Blackwell Science.

Bousso T., 1996, La pêche artisanale dans l'estuaire du Sine Saloum (Sénégal), Approches typologiques des systèmes d'exploitation. Thèse doctorat Univ. Montpellier II.

Chavance P., Ba M., Gascuel D., Vakily J.M., Pauly D., 2004, Pêcheries maritimes, Ecosystèmes et Sociétés en Afrique de l'Ouest : Un demi-siècle de changement. Actes du symposium international, Dakar (Sénégal), 24-28 juin 2002, Luxembourg, Office des publications officielles des Communautés européennes.

Cleveland W.S., 1979, Robust locally weighted regression and smoothing scatterplots. J. Am. Stat. Assoc. 74, 829-836.

Diadhiou A., Bastie F., Niang S., 1986, La pêcherie artisanale de poisson en Casamance. In: Le Reste L., Fontana A., Samba A. (Eds.), L'estuaire de la Casamance. Actes du Séminaire ISRA sur la pêche artisanale en Casamance. Ziguinchor, juin 1986, ISRACRODT, Dakar, pp. 111-124.
Diouf P.S., 1996, Les peuplements de poissons des milieux estuariens de l'Afrique de l'Ouest : l'exemple de l'estuaire hyperhalin du Sine Saloum. Thèses et Documents Microfichés n¹56, ORSTOM, Paris.

Diouf P.S., Kébé M., Le Reste L., Bousso T., Diadhiou H.D., Gaye A.B., 1991, Plan d'action forestier, pêche et aquaculture continentales, Vol. 1, Diagnostic. Projet CRODT/MDRH/FAO, Ministère du Développement rural et de l'Hydraulique, Dakar, Sénégal.

Dorr J.A., Schneeberger P.J., Tin H.T., Flath L.E., 1985, Studies on adult, juvenile and larval fishes of the Gambia River, West Africa, 1983-1984. Report n 11, Great Lakes and Marine Waters Center international programs, The University of Michigan, Ann Arbor, Michigan.

Ecoutin J.M., Durand J.R., Laë R., Hié Daré J.P., 1994, Exploitation des stocks. In: Durand J.R., Dufour P., Guiral D., Zabi S.G.F. (Eds.), Environnement et ressources aquatiques de Côte d'Ivoire. Tome 2. Les milieux lagunaires. ORSTOM, Paris, pp. 399-444.

Ecoutin J.M., Barry M., Bouju S., Charles-Dominique E., Journet O., Penot E., Rue O., Souaré D., Sow M., 1999, Aménagement technique du milieu. In: Cormier-Salem M.C. (Ed.), Rivières du Sud, Sociétés et mangroves ouest-africaines. Edition de l'IRD, Paris, pp. 209-268.

Fisheries Department of the Gambia 1983, Frame Survey. Banjul, Gambia.

Fisheries Department of the Gambia 1997, Frame Survey. Banjul, Gambia.

Garcia S., 1996, Stock recruitment relationships and the precautionary approach to management of tropical shrimp fisheries. Mar. Freshwater Res. 47, 43-58.

Guiral D., Albaret J.J., Baran E., Bertrand F., Debenay J.P., Diouf P.S., Guillou J.J., Le Loeuff P., Montoroi P., Sow M., 1999, Les écosystèmes à mangrove. In: Cormier-Salem M.C. (Ed.), Rivières du Sud, Sociétés et mangroves ouest-africaines. Edition de l'IRD, Paris, pp. 63-130.

Kebe M., 1994, Étude des systèmes de production et de commercialisation dans le secteur des pêches au Sine Saloum. Doc. Scient. CRODT, 140.

King H., 1979, A review of the state of the fisheries in the Gambia. Fisheries Department, Ministry of Agriculture and Natural Resources, Fisheries Publication 32.

Lamagat J.P., Albergel J., Bouchez J.M., Descroix L., 1990, Monographie hydrologique du fleuve Gambie. ORSTOM; Organisation pour la Mise en Valeur du fleuve Gambie (OMVG), Dakar, Sénégal.

Leendertse K., 1995, Management Aspects in Estuarine Shrimp Fishing in the River Gambia. Integrated Coastal Fisheries Management in the Gambia. FI: DP/INT/91/007, Field Document 5, FAO, Rome.

Le Reste L., 1984, Étude des variations annuelles de la production de crevettes dans l'estuaire de la Casamance (Sénégal). Etud. Rev. CGPM 61, 253-269.

Le Reste L., 1986, La pêche crevettière artisanale en Casamance. In: Le Reste L., Fontana A., Samba A. (Eds.), L'estuaire de la Casamance. Actes du Séminaire de l'Institut Sénégalais de Recherche Agronomique sur la pêche artisanale en Casamance, Ziguinchor, juin 1986, ISRA-CRODT, Dakar, Sénégal, pp. 245-256.

Le Reste L., 1992, Variations spatio-temporelles de l'abondance et de la taille de la crevette Penaeus notialis en Casamance (Sénégal). Oceanol. Acta 4, 327-332.

Le Reste L., 1994, Variations spatio-temporelles des prises et de la taille des crevettes Penaeus notialis dans l'estuaire sursalé du Saloum (Sénégal). Rev. Hydrobiol. Trop. 27, 129-142. 
Lesack L.F.W., 1986, Estimates of catch and potential yield for the riverine artisanal fishery in the Gambia, West Africa. J. Fish Biol. 28, 679-700.

Lesack L.F.W., Drammeh O.K.L., 1980, Distribution of effort and structural aspects of the artisanal fishery in the Gambia. Fisheries Department, Ministry of Agriculture and Natural Resources, Fisheries Publication 33.

Lesack L.F.W., Hecky R.E., Melack J.M., 1984, Transport of carbon, nitrogen, phosphorus and major solutes in the Gambia River, West Africa. Limnol. Oceanogr. 29, 816-830.

Lhomme F., 1981, Biologie et dynamique de Penaeus (Farfante Penaeus) notialis (Perez Farfante 1967) au Sénégal. Mém. Thèse Univ. Paris 6, Paris.

Lhomme F., Garcia S., 1984, Biologie et exploitation de la crevette Penaeide au Sénégal. In: Gulland J.A., Rothschild B.J. (Eds.), Penaid shrimps: their biology and management. Fishing News Books, Farnham, UK, pp. 111-144.

Marius C., 1985, Mangroves du Sénégal et de Gambie, écologiepédologie-géochimie- mise en valeur et aménagement. Coll. Travaux et Documents 193, ORSTOM, Paris.
Njai S.E., 2000, Traditional fish processing and marketing of the Gambia. UNU-Fisheries Training Programme, Final Project, Reykjavick, Iceland.

Reizer C., 1974, Définition d'une politique d'aménagement des ressources halieutiques d'un écosystème aquatique complexe par l'étude de son environnement abiotique, biotique et anthropique. Thèse dr., Arlon Full, 6 vol., Univ. Liège.

Ronnback P., Troell M., Kautsky N., Primavera J.H., 1999, Distribution pattern of shrimps and fish among Avicennia and Rhizophora microhabitats in the Pagbilao mangroves, Philippines. Estuar. Coast. Shelf Sci. 48, 223-234.

Scherrer B., 1984, Biostatistique. Gaëtan-Morin Ed., Montréal, Paris. Thayer G.W., Colby D.R., Hettler W.F., 1987, Utilisation of the red mangrove prop root habitat by fishes in south Florida. Mar. Ecol. Progr. Ser. 35, 25-38.

Vance D.J., Haywood M.D.E., Staples D.J., 1990, Use of a mangrove estuary as a nursery area for postlarval and juvenile banana prawns, Penaeus merguiensis de Man, in northern Australia. Estuar. Coast. Shelf Sci. 31, 689-701.

Welcomme R.L., 1985, River fisheries. FAO Fish. Tech. Pap. 262. 